\title{
Temperament of school going children
}

\author{
V. SHAHI, S. BALDA AND S. KAUSHAL
}

Received: 03.08.2013; Revised: 19.10.2014; Accepted: 02.11.2014

See end of the paper for authors' affiliations

\section{S. KAUSHAL}

Department of Home Human Development and Family Studies, C.C.S. Haryana Agricultural

University, HISAR (HARYANA) INDIA

Email: skausha153@gmail.com
ABSTRACT : Temperament is a core element of the human's personality. Child's temperament might be involved in the child's social relationship and affect his or her social development. This study aims to investigate temperamental dimensions of children studying at schools affiliated to Central Board of Secondary Education and Haryana Board of Secondary Education. From Hisar city, two schools affiliated to CBSE and two schools affiliated to HBSE were selected at random. From each school 40 children were randomly selected. Total sample comprised 160 children ( 84 boys and 76 girls). Malhotra Temperament Schedule (Malhotra and Malhotra, 1988) was used to assess mothers' perception of their children's temperament. Results revealed that there were no differences between boys and girls in sociability, emotionality, distractibility and rhythmicity but boys were more energetic than girls.

KEY WORDS: Temperament, School going children, Social development

n HOW TO CITE THIS PAPER : Shahi, V., Balda, S. and Kaushal, S. (2014). Temperament of school going children. Asian J. Home Sci., 9 (2) : 496-499. 